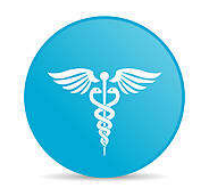

International Journal of Advances in Pharmacy and Biotechnology

Vol.2, Issue-4, 2017, 1-6

Research Article

Open Access.

I J A P B

ISSN: 2454-8375

\title{
EVALUATION OF WOUND HEALING ACTIVITY OF ACALYPHA FRUTICOSA ROOT EXTRACT IN RATS
}

\author{
Afreen Nishath ${ }^{1}$, Sharavana bhava Bandaru Sheshagiri', Gireesh Kumar M², $^{2}$ \\ Venkateshwarlu Eggadi ${ }^{*}$ \\ ${ }^{1}$ Department of Pharmacology, Vaagdevi College of Pharmacy, Warangal, Telangana, Kakatiya University- \\ 506001, India. \\ ${ }^{2}$ Department of Psychiatry, Kakathiya Medical College, Warangal, Telangana, Kakatiya University-506001, \\ India. \\ *Corresponding author e-mail: drgireesh18@gmail.com
}

Received: 30 October 2016

Revised: 18 October2016

Accepted: 20 October 2016

ABSTRACT:

A wound is a breakage in tissue continuity that can be produced by physical, chemical and thermal damage. It is a generally called as physical injury that cause opening and breaking of skin. Healing of chronic cutaneous wound is a big problem and it involves the restoration of continuity after wounding. The Primary objective of this present study is to evaluate the wound healing activity of Ethanolic extract of roots of Acalypha fruticosa. In this perspective, Ethanolic extract of roots of Acalypha fruticosa was taken and excision wound model was used for the screening of wound healing activity. Mupirocin was taken as standard drug. The percentage of wound contraction and period of epithelization was determined. The wound healing activity of Ethanolic extract of Acalypha fruticosa was showed significant wound healing activity with doses 100 and $200 \mathrm{mg} / \mathrm{kg}$. An acceleration of wound healing in Acalypha fruticosa treated rats as compared to the control. Further detailed phytochemical investigations are required to identify the phytoconstituents responsible for the wound healing activity.

Key words: Wound healing, Acalypha fruticosa, Excision, Mupirocin.

\section{INTRODUCTION:}

Medicinal plants constitute a source of raw materials for both traditional systems of medicine (e.g. Ayurvedic, Chinese, Unani, Homeopathy, and Siddha) and modern medicine. Now days, plant materials are employed throughout the industrialized and developing world as home remedies, overthe-counter drugs, and ingredients for the pharmaceutical industry. As such, they represent a substantial proportion of the global drug market. Most rural populations, especially in the developing world, depend on medicinal herbs as their main source of primary health care. Although most medicinal herbs are not in their natural state fit for administration but preparations suitable for administration are made according to pharmacopeial directions. The therapeutic potential of a herbal drugs depends on its form: whether parts of a plant or simple extracts or isolated active constituents. Now a day's many synthetic and herbal medicines are available in the market which is used to treat various ailments [1].

A wound is a breakage in tissue continuity that can be produced by physical, chemical and thermal damage. It is a generally called as physical injury that cause opening and breaking of skin. Healing of chronic cutaneous wound is a big problem and it involves the restoration of continuity after wounding. Wounds are treated with various medicinal herbs or their extracts. Plants provide various remedies to mankind and herbal plants are nature's gift used to treat wound with much 
lesser side effects. Some of those plants are Acalypha langiana, Tinospora cardifolia, Tragiain volucrata, Napoleona imperialis, Proso piscineria, Lawsonia alba, Ginkgo biloba, Aloe vera and Catharanthus roseus [1].

Acalypha is the fourth largest genus of the Euphorbiaceae family. It consists of 450 species, in the form of evergreen shrubs, trees and annuals, mainly in the tropical regions of Africa, America and Asia [2]. Acalypha fruticosa is an erect shrub, up to $1 \mathrm{~m}$ tall, with strong aromatic odour. It has various traditional uses, a cure for stomachache, dyspepsia,venom antidote, rheumatism and dermatitis [3]. The plant has also been subjected to several biological investigations, concerning its antioxidant, anti-inflammatory, and cytotoxic properties [4]. A. fruticosa is also used as sand fly repellent, and used in ethno veterinary practices, as it demonstrates similar medicinal properties in both humans and animals [2].

\section{MATERIALS AND METHODS}

Plant collection: The Roots of Acalypha fruticosa were collected from Tirupati, Andhra Pradesh, India. The roots were identified and authenticated by Prof. K. Madhava Chetty, Department of Botany, and Sri Venkateswara University. The plant specimen was deposited at Botany Department of Venkateswara University With Voucher number 1252.

Animals: Healthy Wistar albino male rats weighing 150-200 g were used for the study which was procured from mahaveera enterprises, Hyderabad. They were housed individually in polypropylene cages, maintained under standard conditions $(12 \mathrm{~h}$ light and $12 \mathrm{~h}$ dark cycle, $25 \pm 30^{\circ} \mathrm{C}, 35-60 \%$ relative humidity), the animals were fed Committee (IAEC), Vaagdevi College of Pharmacy, Warangal, Telangana.
Acute oral toxicity studies: Male swiss albino rats were used and the procedure was followed by using OECD 423[5].

\section{Evaluation of wound healing activity:}

Excision Wound Model: Animals in each group were anaesthetized a full thickness of the excision wound of circular area (approx. 500 $\mathrm{mm}^{2}$ ) and $2 \mathrm{~mm}$ depth was made on the shave back under mild ether. The animals were divided into four groups. Group I treated with control (simple ointment base), group II treated with test 1 (100 mg / kg), group III treated with test $2(200 \mathrm{mg} / \mathrm{kg})$, group IV treated with standard drug mupirocin ointment. The wounding day was considered as day 0 . Rats were left undressed to open environment. To determine the rate of wound contraction, excision wounds were traced on a transparent paper having a millimeter scale and the change in wound size was calculated as the percentage of wound area that had healed. The period of epithelialilzation of the wound was expressed as the number of days taken for complete epithelialization (so that no raw was left behind) [6]. The wounds are monitored and the area of wound was measured on $4,6,8,10,12,16$ post-wounding days and the mean \% wound closure is reported [6].

The Period of Epithelization: The period of epithelization was calculated as the number of days required for falling of the dead tissues remants without any residual raw wound in excision wound model [6].

Statistical Analysis: All results were expressed as mean \pm S.D. and the results were compared statistically by One-Way ANOVA Test using Graph pad Prism software (student version 5). The $\mathrm{P}$ value $<0.05$ was considered statistically significant. 


\begin{tabular}{|c|c|c|c|c|}
\hline \multicolumn{5}{|c|}{ Table 1: Calculation of $\%$ wound contraction } \\
\hline \multirow{2}{*}{$\begin{array}{c}\text { Post } \\
\text { wound } \\
\text { day }\end{array}$} & \multicolumn{4}{|c|}{ Wound Area in $\mathrm{mm}^{2}$ (\% wound contraction) } \\
\hline & Control & Standard & $\mathrm{T} 1(100 \mathrm{mg} / \mathrm{kg})$ & T2 (200 mg/kg) \\
\hline 0 & $500.76 \pm 20.86$ & $517.48 \pm 24.64$ & $497.31 \pm 20.44$ & $500.76 \pm 20.86$ \\
\hline 2 & $\begin{array}{c}455.60 \pm 14.24 \\
(9)\end{array}$ & $\begin{array}{c}406.81 \pm 24.32^{* * *} \\
(21.3)\end{array}$ & $\begin{array}{c}428.58 \pm 15.57^{* * *} \\
(13.8)\end{array}$ & $\begin{array}{c}398.06 \pm 29.47^{* * *} \\
(20.4)\end{array}$ \\
\hline 4 & $\begin{array}{c}395.08 \pm 28.23 \\
(18.5)\end{array}$ & $\begin{array}{c}216.35 \pm 19.04^{* * *} \\
(58.2)\end{array}$ & $\begin{array}{c}236.26 \pm 16.23^{* * *} \\
(52.4)\end{array}$ & $\begin{array}{c}227.18 \pm 14.38^{* * *} \\
(54.6)\end{array}$ \\
\hline 6 & $\begin{array}{c}256.41 \pm 21.95 \\
(42.8) \\
\end{array}$ & $\begin{array}{c}133.05 \pm 14.42^{* * *} \\
(74.2)\end{array}$ & $\begin{array}{c}152.45 \pm 16.20^{* * *} \\
(59.3)\end{array}$ & $\begin{array}{c}125.55 \pm 17.28^{* * *} \\
(64.9)\end{array}$ \\
\hline 8 & $\begin{array}{c}249.88 \pm 11.95 \\
(50.1)\end{array}$ & $\begin{array}{c}77.85 \pm 14.81^{* * *} \\
(84.9)\end{array}$ & $\begin{array}{c}96.2 \pm 87.8^{* * *} \\
(65.56)\end{array}$ & $\begin{array}{c}76.65 \pm 16.65^{* * *} \\
(74.7)\end{array}$ \\
\hline 10 & $\begin{array}{c}229.30 \pm 10.06 \\
(54.2)\end{array}$ & $\begin{array}{c}43.4 \pm 6.71^{* * *} \\
(91.6)\end{array}$ & $\begin{array}{c}60.28 \pm 7.18^{* * *} \\
(70.8)\end{array}$ & $\begin{array}{c}35.4 \pm 9.34^{* * *} \\
(82.9)\end{array}$ \\
\hline 12 & $\begin{array}{c}207.58 \pm 13.37 \\
(58.5) \\
\end{array}$ & $\begin{array}{c}14.33 \pm 3.01^{* * *} \\
(97.2)\end{array}$ & $\begin{array}{c}26.20 \pm 6.49^{* * *} \\
(76.56)\end{array}$ & $\begin{array}{c}11.81 \pm 4.34^{* * *} \\
(87.6)\end{array}$ \\
\hline 14 & $\begin{array}{c}152.35 \pm 12.68 \\
(69.5)\end{array}$ & $\begin{array}{c}5.01 \pm 2.83^{* * *} \\
(99)\end{array}$ & $\begin{array}{c}14.33 \pm 3.51^{* * *} \\
(89.1)\end{array}$ & $\begin{array}{c}4.65 \pm 2.64^{* * *} \\
(91.23)\end{array}$ \\
\hline 16 & $\begin{array}{c}131.1 \pm 7.65 \\
(74.8)\end{array}$ & $\begin{array}{l}2.75 \pm 1.59^{* * *} \\
(99.4)\end{array}$ & $\begin{array}{c}5.81 \pm 2.31^{* * *} \\
(92.23)\end{array}$ & $\begin{array}{c}1.78 \pm 1.4^{* * *} \\
(94.26)\end{array}$ \\
\hline
\end{tabular}

\section{RESULTS}

\section{Acute toxicity study}

In the acute toxicity study, EEAF was found to be safe up a dose of $2000 \mathrm{mg} / \mathrm{kg}$. So, two doses i.e., 100 and $200 \mathrm{mg} / \mathrm{kg}$ were selected for the evaluation of wound healing activity.

\begin{tabular}{|c|c|}
\hline \multicolumn{2}{|c|}{$\begin{array}{c}\text { Table 2: Period of Epithelization in excision } \\
\text { wound model treated by EEAF ointment }\end{array}$} \\
\hline Group & Period of Epithelization (Days) \\
\hline Control & $25.3 \pm 0.81$ \\
\hline Standard & $18.5 \pm 1.51^{* * *}$ \\
\hline T1 & $22.3 \pm 0.51^{* * *}$ \\
\hline T2 & $20.7 \pm 1.22^{* * *}$ \\
\hline $\begin{array}{l}\text { Values were Mean } \pm \text { S.D. (n }=6 \text { ) statistical significance } \\
\text { was determined by ANOVA followed by Dunnet's test } \\
\text { P }<0.0001 \text { when compared to control group. }\end{array}$ \\
\hline
\end{tabular}

\section{Evaluation of wound healing activity:}

The percentage wound contraction was calculated as $92.23 \%$ (100 mg/kg body) and $94.26 \%$ (200 mg/kg) as compared to the control group $74.8 \%$.

\section{Effect on period of epithelization:}

The period of epithelization was found to be 22.3 days $(100 \mathrm{mg} / \mathrm{kg})$ and 20.7days (200 $\mathrm{mg} / \mathrm{kg}$ ) compared to control 25.3.

\section{DISCUSSION}

The present investigation describes some unique features of the root extract from the plant Acalypha fruticosa with respect to its potential wound healing capacity in rats. Plant products are potential wound healing agents, and largely preferred because of their wide spread availability, non-toxicity, absence of unwanted side effects, and effectiveness as crude preparations. Early dermal and epidermal regeneration in the treated group conformed that the Acalypha fruticosa extract had a positive effect toward cellular proliferation, granulation tissue formation, and epithelization. The treated rats showed marked epitheliazation, a moderate amount of extra cellular matrix synthesis and new blood vessel formation. 


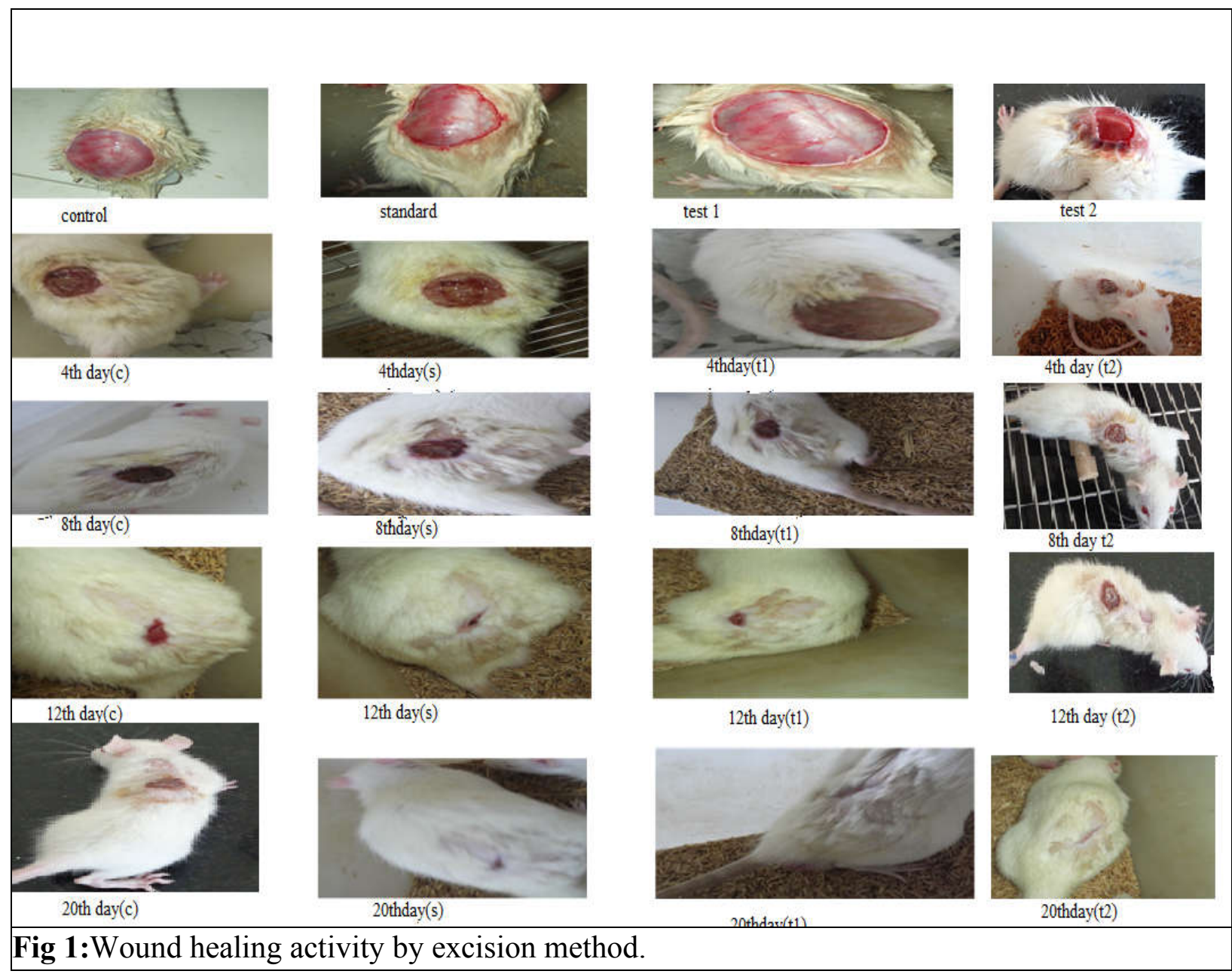

Latex of Calotropis gigantean (200 $\mathrm{mg} / \mathrm{kg} /$ day) was evaluated for its wound healing activity in albino rats using excision and incision wound models. Latex treated animal's exhibit $83.42 \%$ reduction in wound area when compared to controls which was $76.22 \%$. The extract treated wounds are found to epithelize faster as compared to controls. Significant $(p<0.001)$ increase in granulomatous breaking strength (485 \pm 34.64$)$ was observed. The Framycetin sulphate cream (FSC) $1 \% \mathrm{w} / \mathrm{w}$ was used as standard [7].

The results of the present study showed that Acalypha fruticosa possesses a definite prohealing action. In excision wound healing model the ethanolic extract of the roots of the plant Acalypha fruticosa showed significant increase in percentage closure of excision wounds by enhanced epithelization. The www.ijapbjournal.com epithelization may be due to the effect of Acalypha fruticosa on enhanced collagen synthesis. Topical application of Acalypha fruticosa extract ointment increased the percentage of wound contraction and completed wound healing by 20th day. Progression of wound healing by 16 th day i.e T1 92.23 and T2 94.26 compared with control 74.8. It also reduced the period of epithelization from control 25.3 days to $\mathrm{T} 1$ 22.3days to T2 20.7 days. In excision wound healing model the ethanolic extract of the roots of the plant Acalypha fruticosa showed significant increase in percentage closure of excision wounds by enhanced epithelization. The epithelization may be due to the effect of Acalypha fruticosa on enhanced collagen synthesis. The aqueous extract of C. papaya fruit (100 mg kg-1 day-1 for 10 days) was evaluated for its wound healing activity in streptozotocin-induced diabetic rats using 
excision and dead space wound models. Extract-treated animals exhibited $77 \%$ reduction in the wound area when compared to controls which was 59\%. The extract treated wounds were found to epithelize faster as compared to controls. The wet and dry granulation tissue weight and hydroxyproline content increased significantly when compared to controls. The extract exhibited antimicrobial activity against the five organisms tested. Carica papaya promotes significant wound healing in diabetic rats and further evaluation of this activity in humans is suggested [8].

Percentage yield of the extract was $62 \%$ and its colour was Green with semi solid consistency. Preliminary phytochemical investigations of EEAF showed the presence of triterpinoids, steroids, flavanoids, phenols and saponins.

\section{CONCLUSION}

In conclusion, Ointment from the root of Acalypha fruticosa exhibited significant prohealing activity in the infected wound when topically applied on rats by affecting various stages of healing process.

\section{ACKNOWLEDGEMENT}

Authors are thankful to the Secretary, Dr.Ch. Devender Reddy, Viswambhara Educational Society, Warangal, and Telangana for giving us opportunity to work and providing necessary facilities to carry out this Research work.

\section{CONFLICT OF INTEREST}

The author(s) confirm that this article content has no conflict of interest.

\section{REFERENCES}

[1] Rani.S, Amanjot, Gautam, Kanwar, Kapil and Kaur.Wound healing potential of medicinal plants with their screening models: A Comprehensive review. Journal of drug delivery and therapeutics.. 2016;6(1):56-66.

[2] R. Seebaluck, A. GuribFakim, F. Mahomoodally. Medicinal plants from the genus Acalypha (Euphorbiaceae) - A review of their ethnopharmacology and Phytochemistry J. Ethnopharmacol., 159 (2015), pp. 137-157

[3] R.A. Mothana, S.A. Abdo, S. Hasson, F. Althawab, S.A. Alaghbari, U. LindequistAntimicrobial, antioxidant and cytotoxic activities and phytochemical screening of some Yemeni medicinal plants Evid. Based Complement. Alternat. Med., 7 (2010), pp. 323-330.

[4] S. Gopalakrishnan, K. Saroja, J.D. Elizabeth Chemical investigations of aerial parts of Acalypha fruticosa forssk Der Pharma Chem., 2 (2010), pp. 383-389.

[5] OECD (2002), Test No. 423: Acute Oral toxicity - Acute Toxic Class Method, OECD Guidelines for the Testing of Chemicals, Section 4, OECD Publishing,Paris, https://doi.org/10.1787/978926407100 1-en.

[6] A.D.Taranalli, S.V.Tipare, S.Kumar, S.S.Torgal. Wound healing activity of Oxalis corniculata whole plant extract in rats. Indian Journal of Pharmaceutical Sciences.2004: 66(4):444-446.

[7] T. D. Pradeep, F. Jennifer, A. Akarte , T. Emmanuel. Wound healing activity of Calotropis gigantea root bark in rats. Journal of Ethnopharmacology 125 (2009) 178-181

[8] B.S. Nayak, L. P. Pereira, D. Maharaj. Wound healing activity of Carica papaya L. in experimentally induced diabetic rats. Indian Journal of Experimental Biology. 2007 45(8):739-43. 


\section{How to cite this article:}

Afreen nishath et al Evaluation Of Wound Healing Activity Of Acalypha Fruticosa Root Extract In Rats. Int. J. Adv. Pharm. Biotech., 2016; 2(4): 1-6. 